Ssciendo Studia Anglica Posnaniensia 55s2 (2020): 291-301

doi: 10.2478/stap-2020-0014

\title{
ON REFUSING CANADA, CANLIT AND MORE: NATIONAL AND LITERARY IDENTITY IN ALL ITS VARIETIES
}

\author{
NORMAN RAVVIN ${ }^{1}$
}

\begin{abstract}
Two recent anthologies of Canadian writing - Refuse: CanLit in Ruins and Resisting Canada: An Anthology of Poetry - reflect stances of resistance to mainstream institutional understandings of Canadian writing culture. They highlight recent scandals in academia and in literary communities, as well as highlighting the voices of Indigenous and women writers. These stances echo earlier forms of cultural revolution in Canada, in particular the Refus global manifesto, which provoked conventional Quebec society in the late 1940s. This paper contrasts these forms of refusal with a period in the 1950s and 1960s when influential Jewish writers, including Leonard Cohen and Irving Layton, took a counter-cultural stance while appearing in mainstream venues offered to them by $\mathrm{CBC}$ television and radio.
\end{abstract}

Keywords: Canadian literature; CanLit; resistance; Jewish writers; anthologies, CBC.

Not long ago I went to hear my son play electric jazz on Montreal's east side, at a second floor joint called $L^{\prime}$ Escalier, above a defunct newsstand. It was a well named venue, for up the narrow stairs you went to find a seat in one of a puzzle of small rooms, all interconnected by views through doors or over ledges of the tiny stage in the northwesternmost corner. I don't go into too many such places bohemian, a little unkempt, yet welcoming - and if such visits cease, you stop seeing slogans written on bathroom stall doors like the one I saw that afternoon: "No Pipelines on Stolen Land: Say NO to CANADA". The first part of the demand is entirely of the moment, an expression of shifting economic and social attitudes, as well as of attentiveness to global climate change. The second half of the command - "Say NO to CANADA" - has a longer and more complex history, especially if the bathroom door that presents it is on the east side of Montreal. But there is something of the moment in saying "NO to CANADA" in English in

1 Concordia University, Montreal 
east Montreal. The social and political equations are different today than they were in 1995, 1980 or 1976, when Québécois nationalism motivated the most outspoken voices who insisted on saying "NO" to a country.

Rebellion. Rejection. Refusal. These have all had a complex history in Quebec. The province's most famous twentieth-century cultural manifesto of refusal was self-published - no professional publisher stepped forward to take up the job - by the painter Paul-Émile Borduas in the fall of 1948 under the title Refus global. It is an art-historical document, in part in defense of new kinds of abstract expression, but more overtly it offered a "global" refusal of the province's status quo, of its past leaders who "sold themselves to the highest bidder"; of "age-old bromides" promoted "in Quebec and in seminaries around the world"; of educational institutions that had "absolute control over a world of warped memories, stagnant minds and misguided notions". "Christian civilization is coming to an end", Borduas announced to the province's priests and its governing class, so to "Hell with the aspergillum and the toque" (1948 n.p.). ${ }^{2}$

Borduas' is surely a global refusal, aimed at the social, political, and religious authorities who ran Quebec. At exactly the same time, in the same city, though some blocks west, a different view of Canadian political, social and religious power was conveyed by the poet A. M. Klein. In the immediate postwar years from 1945 to 1947 - Klein wrote his iconic poems of place and local culture, which were collected in The Rocking Chair and other Poems. In return for its evocation of the country and its ideals, Klein was awarded the Governor General's Prize in 1948. The Rocking Chair includes a few discordant notes of political refusal (in particular, the condemnation of Montreal's wartime mayor Camillien Houde and his appeal to the "body-odour of race" (Klein 1951b [1948]: 16)). But beyond this, Klein's poems of the late forties search for shared icons and symbols of national, even tribal meaning and resonance. If one could write, in those years, a poem that inscribed the whole of the country, why not "Grain Elevator", which muses upon the gargantuan silos of Montreal's port, which Klein compares to biblical monsters and Noah's ark. Things "out of legend", the silos link central Canada with faraway western provinces:

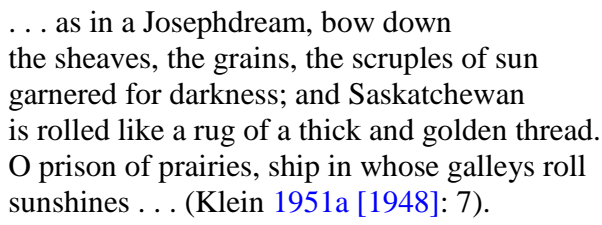

2 An aspergillum is an implement used by a priest to sprinkle holy water. Its juxtaposition with the headgear of the supporters of the ruling Union Nationale party is a smart surrealistic touch. 
Klein's "Grain Elevator" signals the anthologist's dream of capturing all of midcentury Canada, of gathering up the themes, the motifs, symbols, and narratives, which might evoke and hold up the whole country for special appreciation. Klein's is the opposite strategy to that of Borduas and the others who signed his manifesto of refusal of place and time.

My bathroom door provocation - "No Pipelines on Stolen Land: Say NO to CANADA" - might signal a new way of saying "NO to CANADA" (I reproduce its typography, which presents the name of the country as we see it on our currency). Its current underpinnings are evident on the streets, and on the signs held at railway blockades, as well as in the op-ed columns of newspapers and news web sites. This new way of saying "NO to CANADA" informs two recent anthologies, which, resembling the Refus global manifesto, insist on a broad refusal of Canadian history, political institutions, and social hierarchies. One of these, Resisting Canada: An Anthology of Poetry, was published in Montreal in 2019 by Véhicule Press. If Klein's The Rocking Chair, published more than seventy years before, aimed to represent the country whole, Resisting Canada insists on a total refusal of the country's status quo. The anthology's editor, Nyla Matuk, explains that to

resist Canada is to first acknowledge that the Canadian state was, and is, a settlercolonial endeavour. It was created atop the territories whose caretakers were or are Indigenous Peoples, sovereign bodies who populated the land and cared for it before European colonizers arrived. Driving settler-colonialism, and informing it a priori, is racism; that is, the assumption on the part of the colonizer that those who already inhabit and care for the land are not fully human beings, are not deserving of rights, or, most conveniently, can be transferred, assimilated, or eliminated. When I refer to the Canadian state, I'm including all levels of government operating inside federalism, as well as its associated institutions, symbologies, and official patriotic paraphernalia. References to the state also include colonizer mythology, in which the land was believed to be without people with a culture and society, a terra nullius ... (2019: 15-16).

A "colonizer mythology" was written into the leading theoretical underpinnings of Canadian literature by Northrop Frye in his 1965 "Conclusion to the Literary History of Canada". "After the pioneer period," Frye wrote, to

feel "Canadian" was to feel part of a no-man's land with huge rivers, lakes, and islands. ... One wonders if any other national consciousness has had so large an amount of the unknown, the unrealized, the humanly undigested, so built into it. (2003 [1965]: 346)

Frye's notion of a struggle with unfathomable wilderness was given further credence by his student, Margaret Atwood, most influentially in her bestselling Survival: A Thematic Guide to Canadian Literature (1972). The contrast between 
these explorations of Canadian culture and Borduas' is striking. For him, it was not the landscape, nor its bitter challenge to human community, which was at the heart of a French-speaking Montrealer's existential challenge. Rather, it was his ancestors, their colonial disaster, and its social and political outcomes in postwar Quebec with which the Refus global manifesto aimed to do battle.

Literary resistance in Resisting Canada targets "the denialist culture of settler states", while upholding "the traditional cultures, languages, and values of Indigenous Peoples", and interrogating "historic texts" that maintain oppressive ideologies (Matuk 2019: 23, 26). Pipelines in Alberta, which cross Indigenous territory for which no treaty was signed, are characterized as the "'biggest and most destructive industrial project[s] in human history" (Matuk 2019: 36). The poems Matuk includes, like Marilyn Dumont's "Letter to Sir John A. Macdonald", assert these themes while critiquing national history and ideology:

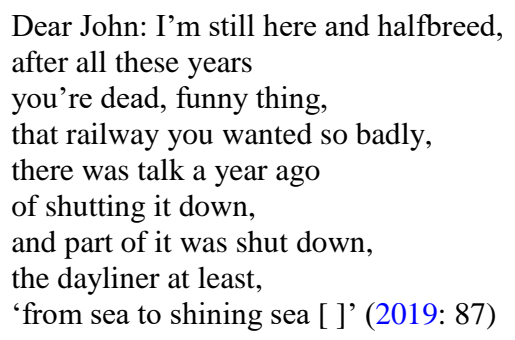

Refuse: CanLit in Ruins, a collection of essays published one year before Resisting Canada, employs in its title the word so crucial to Borduas' provocation to Quebec cultural hierarchies. The volume's three editors - Hannah McGregor, Julie Rak, and Erin Wunker - are based outside Quebec and do not seem to have that early use of the term in mind. But they do recognize the word's multiple meanings and potential in relation to literary canon and industry:

\footnotetext{
We think of "refuse" in many ways. It is saying "no" to the serious inequities, prejudices, and hierarchies that exist within Canadian literature as an industry (often shortened to "CanLit") and an area of academic study. "Refuse" is another word for garbage, for waste. And what wastes our time, and our lives as writers and teachers, is the kind of endorsement of the status quo that we want to see taken out of CanLit. But "refuse" can also mean "re/fuse," to put together what has been torn apart, evoking the idea that, after something is destroyed, something better can take its place. No matter what we mean by "refuse," this much is clear: after a series of controversies and scandals, the signifier "CanLit" currently lies in ruins. (McGregor, Rak \& Wunker 2018: 9)
}

The political, social, and economic terms of reference applied in Refuse: CanLit in Ruins do not highlight Indigenous history and rights, as does Resisting Canada. 
Instead, they reject the hierarchies and ideology of Canadian literature, whether in university departments, publishing programs, the arts media, or government granting agencies. As the introduction to Refuse: CanLit in Ruins explains, a "series of controversies and scandals" that took place between 2015 and 2018 motivated the authors collected in the volume to say "NO" to CanLit. The scandals are these: the fallout in response to an online open letter, spearheaded by writer Joseph Boyden and signed by some 80 writers, under the title UBC Accountable, which criticized the University of British Columbia's handling of harassment and assault allegations against Steven Galloway, the head of its Creative Writing department. This was followed, but almost overlapped with the revelation by a reporter for the Aboriginal Peoples Television Network, which presented Boyden's claim of Indigenous ancestry as unsupported, alongside his potential plagiarism of an Indigenous elder's story. As the details of Galloway's relationship with students worked their way through the press, a full revelation without the names of perpetrators - was made of longstanding complaints regarding abusive behaviour by male Creative Writing professors toward female students at Concordia University in Montreal. In this instance, a male student connected with the accused instructors gained the media's attention by way of a blog post, without directly acknowledging the women who had launched complaints with Concordia administrators. Spread as they were across the country, linking academic, writerly, and the broader media culture, these scandals revealed abuse and inequalities in the institutions that cultivate and support Canadian literature.

The "NO" to CanLit lodged by the editors and contributors to Refuse: CanLit in Ruins is, too, a "NO to CANADA". As the collection's editors see it, "literary production of / in / about Canada" has "become so centralized, so industrialized, so organized around a notion of national identity" that the country's literature and its economic, social, and ideological underpinnings are interrelated parts of one project (McGregor, Rak \& Wunker 2018: 19). Just as Nyla Matuk envisions the contributions to Resisting Canada as refusals of the authoritative ideologies and institutions that underwrite the Canadian state, so the editors of Refuse: CanLit in Ruins view Canadian literature as "[i] rrevocably imprinted with the sign of the state, funded through initiatives rooted in cultural nationalism". (McGregor, Rak \& Wunker 2018: 21) This "imprint" ensures that CanLit mirrors the country's "exclusive" categories, which police the "boundaries of who counts as Canadian and who does not" (McGregor, Rak \& Wunker 2018: 20-21). Refusing these elements of CanLit includes a broader "NO to CANADA", a contemporary global refusal.

Who a tradition allows in is, at all times, a measure of its ethics and its politics. Canadian literature in English (in the decades before it gained the nickname CanLit) was a full-throated echo of the English literary canon with modernist American influences arriving in the 1940s. Its first important ethnic component 
was contributed by Jewish writers, most of whom were born in Montreal, Toronto, and Winnipeg, though some had been brought to Canada from eastern Europe as children. A. M. Klein rose to prominence first, publishing his poetry in journals in both the United States and in Montreal. Klein was welcomed for his modernist affiliations and impressed his compatriots with his dedicated and appreciative allusions to the British poetic tradition. He was a polyglot, steeped in Jewish traditions and materials, yet his work carried within it key influences that the mainstream held dear. Prominent writers whose careers developed in the late forties and early fifties included Irving Layton, Henry Kreisel, Miriam Waddington, Norman Levine, Mordecai Richler, Adele Wiseman, Eli Mandel, and Leonard Cohen. Poets and prose writers, westerners and central Canadians, their work appeared in anthologies and later in academic contexts. In the latter case, there was a notable absence of Jewishly informed literary critical reception well into the career of Cohen, the youngest of the group. Reviewers, general readers, and, in the hey-day of literary shows at CBC Radio and TV, broadcasters, defined the reception received by this new group of Canadian writers. On shows moderated by Pierre Berton, Adrienne Clarkson, Elaine Grand, and Beryl Fox, the new Jewish component of the nation's literature confronted mainstream culture and conformity. Each interviewer took a different approach, to a degree; Berton was most affronted; Clarkson was willing to be coy; Grand tried to treat Richler like a buddy; only Fox exhibited genuine personal interest in what it was that Cohen's literary celebrity meant to the average Canadian. Sometimes, in surprisingly moderate ways, these writers said "NO" to the CBC's way of broadcasting the voice of Canadian authority.

Jewish voices of refusal found in interviews on CBC Radio and TV in the 1950s and '60s stand in contrast with the form of refusal expressed in Resisting Canada and Refuse: CanLit in Ruins. The CBC interviews, viewed through this lens, come into focus in a new way. Puzzling interactions, discomfiting interplay, misunderstanding and hesitation take on clearer meaning. This is true even if one assumes that author and interviewer are only vaguely, if at all aware of what underlies their disagreement. Throughout the TV and radio interviews available on the CBC's online Digital Archives, there is no sustained discussion of Jewishness. ${ }^{3}$ The idea of a multicultural literature, of a minority literature

3 The CBC Digital Archives web site recently underwent a facelift, removing background context for each entry. Its older format, revealing broadcast date and details for radio and TV programs, remains accessible online. Linda Morra, in an essay on CBC Radio broadcasts presented in the Digital Archives, differentiates between "more traditional holdings that contain broadcast recordings and other operational records . . . housed within official CBC" buildings, and the online Digital Archives, which are organized to showcase "how CBC Radio is invested in appealing to and educating the masses, a generalized audience rather than a scholarly one" (2019: 37-38). 
providing a counterweight to mainstream writing, was so far off in the future that such subjects did not require attention. Evidence of this is found when Irving Layton and Miriam Waddington appear as part of a four person panel on "Fighting Words", to debate whether CBC "monopolizes Canada's intellectuals", as well as on the short-lived poetry-themed show "Extension", hosted by poet Phyllis Web in 1967 (Does CBC 1961). There Layton and Waddington discuss political themes in Canadian poetry of the 1930s and 1940s without dwelling on Jewish history or daily life.

When an author is invited to speak about their own work, criticism - whether by outside reviewers or the author's "community", loosely named - is a regular theme. Richler and Cohen express exasperation with reviewers' treatment of their work. In a 1963 interview, following the release of Cohen's first novel, he compares Canadian reviewing to "head patting", adding that "in Canada there isn't even any standard of reviewing" (Playing 1963). This theme comes up more vigorously in a 1966 interview with Adrienne Clarkson. Clarkson opens the segment with a litany of stridently negative coverage of Cohen's second novel, Beautiful Losers, described by Robert Fulford as "the most revolting book ever written in Canada" (Beautiful Losers praised 1966). Why, one wonders, would the nation's premier broadcaster put the writer of such a book on TV for national coverage? The point, it seems, was to challenge the author, and Clarkson is surprisingly willing to question Cohen's embrace of the "happy revolution" he says he has encountered in Toronto's Yorkville. Of his novel's critics, he tells Clarkson, "I'd feel pretty lousy if I were praised by a lot of the people that have come down pretty heavy on me". As the disagreement between interviewer and subject deepens, Cohen's tone shifts ever so slightly and he adds, "There's a war on ... It's an old, old war ... If I have to choose sides, well, I'd just as well be defined as a has-been by the establishment press". It's an odd position to find oneself in as a writer: invited onto a major platform of the establishment press to be coaxed and cajoled into denouncing the press.

In 1966 the war, concretely, was in Vietnam, and American advisors were beginning to view it as unwinnable. But in the context of a discussion of literature and youth culture - however lightly focused on Beautiful Losers itself, no words of which are heard in the course of the interview - the point of conflict is the culture war exemplified by Cohen's "happy revolution" (Beautiful Losers praised 1966). These concerns are at the centre of his song "There is a War" from the 1974 album New Skin for the Old Ceremony:

There is a war between the rich and poor

There is a war between the man and the woman.

There is a war between the ones who say, There is a war,

And the ones who say that there isn't. (Cohen 1974: 59) 
In his argument with Clarkson, what sort of refusal does Cohen express? Where does refusal of Canada enter the argument, in addition to the drama of an author being invited onto the stage of the country's national broadcaster to explain himself on personal and professional grounds? (In interview after interview Cohen, Richler, and Layton are offered the country's major media platform, often in elegantly staged and lengthy formats, in which the discussions do not address their literary works but a host of other social or autobiographical questions. It is as if the writer is made to stand in for something other than him or herself; as a testing ground for reigning notions of Canadianness. Is it the writers' potential refusal that makes them enticing panelists?)

Cohen is routinely interrogated about his opinions regarding rising Quebec nationalism. On this subject, as a Jewish English-speaking Quebecer, his ideas are idiosyncratic, even provocative for their time. "The original concept of Confederation as a partnership has" not been honoured, he says, and should be "re-established". Both French and English speakers in Montreal, Cohen adds, recognize the separatist movement as a "very healthy indication of an awakening people . . . I certainly would like to tap the energy of this complete change of mind that is occurring in my province" (Leonard Cohen 1963). The interviewer sounds surprised at this response, yet there is nothing in the questions that follow that signals curiosity about such ideas coming from a young Jewish Westmounter. Cohen's ideas, an expression of identity in time and place, are not part of the interviewer's playbook. In this appearance, like many others, the lack of attention to the role of Jewishness in Cohen's work and views is notable. Cohen mentions his forthcoming poetry volume, Flowers for Hitler, whose provocative title elicits not a word of comment from the interviewer. Could it be that he thought that any number of poets, Jewish or not, were going around offering their poems with flowers for Hitler?

Cohen's willingness to speak in favour of Quebec nationalism is provocative in the context of a $\mathrm{CBC}$ interview, as an expression of some sort of "NO to CANADA", even though it is offered in a tone of enthusiastic inclusiveness. Mordecai Richler takes a more idiosyncratic stance in a 1961 interview for the CBC television show "Close-Up". Interviewer Elaine Grand finds Richler in what appears to be his London flat to ask how he feels about his reception back home and about Canada overall. The success of The Apprenticeship of Duddy Kravitz lurks in the background, as does the displeasure it is said to have raised in Mordy's community - so Grand dubs Richler as she strives to rouse him from his sullen disinterest in the proceedings. Richler's body language, his tone, his incessant smoking, radiate one long unvoiced Richlerian "NO" to the interviewer. Grand and Richler hardly address literature itself, but focus instead on Canada from the point of view of a young writer abroad. Richler is perversely negative about Canadian cultural developments, laughing at a recent Toronto conference 
funded by the Canada Council (the funder of his early novels) and hailing bowling alleys and golf courses when Grand asks him to say what he appreciates about Canada. Richler's slumping, unsmiling disdain underlines his refusal to play to the camera that will broadcast him back home - who cares, he seems to think, what the rubes at the bowling alley think? - but he is direct in his unwillingness to acknowledge whether Canada "has a national culture at all" (Mordecai Richler: apathy 1961). "The truth is", he says of Canadians, "we want nothing so much as to be American. ... I for one would rather we chucked it all and joined the United States and stopped defying the logic of politics and geography" (Mordecai Richler: apathy 1961). Saying this in 1961, with American involvement in the Vietnam War underway, places Richler on the wrong side of Cohen's war. Two kinds of refusal then, from two very different Canadian Jewish authors, but refusal all the same.

The Jewish writers of the 1950s and ' 60 s are outliers, called out in new ways by mainstream interviewers and reviewers, even if their Jewishness is not an acknowledged aspect of the ongoing debate. What of the non-Jews who found themselves in similar positions? In Refuse: CanLit in Ruins, journalist and creative writer Erika Thorkelson points to Margaret Atwood's CBC appearances in the late sixties and early seventies, which pitted author against interviewer: "The CBC archives are full of evidence of Atwood employing her acidic wit to cut down interviewers who ask silly questions about her domestic life, questions they would never consider asking a man" (2018: 187). But this mode of questioning is not about the author's relationship to country. It was singularly dismissive and ignorant, a male authoritative voice laying into a leading Canadian woman writer. Atwood's notable position, Thorkelson argues, at that early stage of her career and that of CanLit, was her "uncompromising refusal to soften to the expectations of a woman writer" (2018: 187). In part because of her early and unchanging support for the UBC Accountable letter, Atwood's status as an iconic feminist voice is under pressure in a number of the pieces included in Refuse: CanLit in Ruins. Atwood's signature on Joseph Boyden's UBC Accountable open letter helped characterize her work and influence as a focal point around which CanLit is "centralized . . . industrialized" and supports "a notion of national identity" (McGregor, Rak \& Wunker 2018: 19).

At times one must grab the opportunity to refuse at great personal risk, as do demonstrators today against pipelines in the Canadian West. At other times the opportunity to refuse is indirectly offered, as with the plentiful CBC venues given Cohen, Richler, and Layton. (A search through the present online offerings of the CBC Digital Archives comes up with no results for early TV or radio platforms offered to Adele Wiseman.) Sometimes there is a ready audience for expressions of refusal; one expects the publishers of Resisting Canada and Refuse: CanLit in Ruins know the constituencies represented by the poetry, memoir, and essays of 
their contributors. But sometimes an audience is unprepared - as they must have been in response to early-sixties interviews with Cohen and Richler - so the impact of such performances is not measurable. Refusal, in such instances, might simply be read as cynicism, or pretentious posing (this is what Layton can be seen to do at almost every opportunity; he was ubiquitous, a monopolizer of CBC panels, to the extent that he is referred to on one occasion as "an old friend of 'Fighting Words"' (Does CBC 1961)). When Borduas was preparing to mimeograph 400 copies of the self-published Refus global manifesto, he advised young writers whose work was to be included to remain anonymous, in order to protect themselves against the storm of criticism that he expected the document would receive from conservative Quebec authorities. Jewish refusal in Canadian literary culture was early, yet it never became an overt subject of discussion. It may be its early and ambiguous character that allows it to be absent, even unspeakable, in Resisting Canada: An Anthology and Refuse: CanLit in Ruins.

\section{REFERENCES}

Atwood, Margaret. 1972. Survival: A Thematic Guide to Canadian Literature. House of Anansi. Beautiful Losers praised and condemned. 1966. CBC Digital Archives. https://www.cbc.ca/player/play/1736790494 (accessed 08/03/2020).

Borduas, Paul-Émile, et al. [1948]. Refus global manifesto. The Canadian encyclopedia. https://www.thecanadianencyclopedia.ca/en/article/refus-global-manifesto (accessed 07/03/2020).

Cohen, Leonard. 1974. There is a war. In New skin for the old ceremony, Amsco Records. 59.

Does CBC monopolize Canada's intellectuals? 1961. CBC TV Fighting words. https://www.cbc.ca/archives/entry/does-cbc-monopolize-canadas-intellectuals-plusdebating-dirty-jokes (accessed 08/03/2020).

Dumont, Marilyn. 2019. Letter to Sir John A. Macdonald. In Nyla Matuk (ed.), Resisting Canada: An anthology of poetry, Véhicule. 87-88.

Frye, Northrop. 2003 [1965]. Conclusion to the literary history of Canada (1st edn). In Northrop Frye on Canada (vol. 12), University of Toronto Press. 339-372.

Klein, A. M. 1951a [1948]. Grain elevator. The rocking chair and other poems, McGraw-Hill Ryerson. 7.

Klein, A. M. 1951b [1948]. Political meeting. The rocking chair chair and other poems, McGrawHill Ryerson. 15-16.

Leonard Cohen on how a "sleazy" Toronto hotel helps. 1963. Assignment. CBC radio. https://www.cbc.ca/radio/q/blog/leonard-cohen-on-how-a-sleazy-toronto-hotel-helps him-write-poetry-1.5108947 (accessed 08/03/2020).

McGregor, Hannah, Julie Rak \& Erin Wunker. 2018. Introduction. Living in the ruins. In Hannah McGregor, Julie Rak \& Erin Wunker (eds.), Refuse: CanLit in ruins, Book*hug. 9-28.

Matuk, Nyla. 2019. Introduction. In Nyla Matuk (ed.), Resisting Canada: An anthology, Véhicule. 15-39. 
Mordecai Richler: Apathy, envy and the great Canadian wasteland. 1961. CBC TV Close-up. https://www.cbc.ca/player/play/1402948216 (accessed 08/03/2020).

Morra, Linda. 2019. CBC radio's digital archives and the production of Canadian citizenship and culture. In Jason Camlot \& Katherine McLeod (eds.), CanLit across media. Unarchiving the literary event, McGill-Queen's University Press. 35-53.

Playing the favourite game. 1963. CBC digital archive. https://www.cbc.ca/player/play/1736797763 (accessed 08/03/2020).

Thorkelson, Erika. 2018. Whose CanLit: Solidarity and accountability in literary communities. In Hannah McGregor, Julie Rak \& Erin Wunker (eds.), Refuse: CanLit in ruins, Book*hug. 184-190. 